\title{
Impact of COVID-19 Pandemic on Households in West Bengal: A Study in Hooghly District
}

\author{
Tanima Choudhury ${ }^{1}$, Souman Samanta ${ }^{2}$, Pranjit Kr Paul ${ }^{3}$, Adwaita Maiti ${ }^{4 *}$
}

\begin{abstract}
${ }^{1}$ Ph.D. Scholar (JRF), Department of Zoology, West Bengal State University, Berunanpukuria, P.O. Malikapur, North 24 Parganas, West Bengal 700126, India

${ }^{2}$ SACT-I, Department of Economics, Prabhat Kumar College, Post- Karkuli, Contai, West Bengal 721404, India

${ }^{3}$ Ph.D. Scholar, Department of Economics, Vidyasagar University, Midnapore, West Bengal 721102, India

${ }^{4}$ Assistant Professor, Department of Economics, Prabhat Kumar College, Post- Karkuli, Contai, West Bengal 721404, India
\end{abstract}

DOI:10.36347/sjahss.2022.v10i01.004

| Received: 06.12.2021| Accepted: 10.01.2022 | Published: 29.01.2022

*Corresponding author: Adwaita Maiti

Assistant Professor, Department of Economics, Prabhat Kumar College, Post- Karkuli, Contai, West Bengal 721404, India

COVID-19 has caused economic shock across the world for taking lockdown. Currently, India has facing a negative GDP growth rate. The economy of West Bengal has been affected a lot because of the strict implantation of lockdowns and also faces natural disasters. Unemployment went up to nearly 24 percent and 18 percent in India and West Bengal respectively in April 2020. The paper aims to investigate the impact of covid-19 pandemic on households' income, consumption and savings. We have conducted a primary survey on 100 households in a small village in the Hooghly district in West Bengal, India, during the month of October 2020. The study reveals that both income and consumption of households has decreased but income decreased more than the consumption expenditure. The study also found overall consumption expenditure decreased but food expenditure increased, that's why people have broken their savings for maintaining food expenditure during this situation.

Keywords: Covid-19, Lockdown, Income, Consumption, Savings, ANOVA.

Copyright ( 12022 The Author(s): This is an open-access article distributed under the terms of the Creative Commons Attribution 4.0 International License (CC BY-NC 4.0) which permits unrestricted use, distribution, and reproduction in any medium for non-commercial use provided the original author and source are credited.

\section{INTRODUCTION}

The COVID-19 has caused a voluminous economic shock across the world for taking socialdistancing measures by the government. The economic crisis has shown in all the infected countries and for developing countries like India. It was really a challenging time, after imposing the nationwide lockdown all economic activities have come to a standstill, various factories were not operating, most markets were closed, all the people were facing disruption in work, income of the crores households were falling day by day in India. It is also reported that almost 90 percent workers badly affected for this situation, especially those were engaged with informal sector without any social employment protection in India (Shegunshi \& Hiremath, 2020). After the implementation of lockdown it was not well for the economy of India which was already deceleration after the year 2016, with the ongoing 4.7 percent of GDP growth rate in 2019 (Trading Economics, 2020).
Similarly, small scale businesses had only just started to recover after shock of the 2016's demonetization which throw-down of cash consuming informal sector (Anand \& Kumar, 2016). Furthermore, the rate of unemployment was high in 2019 in the last 45-years as per the World Bank report. The COVID-19 pandemic and imposition of nationwide lockdown will likely disable the all sector of economy further (Mishra \& Rampal, 2020). The State of West Bengal is also not free from the impact of COVID-19 pandemic; it has caused large extent of difficulties to all working people at entire part of the state. The state's economy has been affected a lots because of strict implantation of lockdowns and the state of West Bengal also faces the natural disaster like 'AMPHAN' which has almost destroyed the districts like Kolkata, Howrah, North and South 24 Parganas, Purba Midnapur, Paschim Midnapur etc. Most of the people of affected districts had fallen down into difficulty by losing their own shelters, crops in the fields and food. The economic condition of West 
Tanima Choudhuryet al., Sch J Arts HumanitSocSci, Jan, 2022; 10(1): 24-31

Bengal has been further damaged because of the millions of reverse migration of labourers who were working in different states like Delhi, Maharastra, Kerala, Tamilnadu and Jharkhand of the country and engaging in informal sectors. All these unprecedented occurrences have already disrupted the people's normal economic activities and also affect the working people who are poor living in rural area, urban slum in the state. The labour classes, those were engaging in informal sectors are having undesirable hit during the lockdown period because of losing running jobs. Households' income was reduced, with zero savings and unfortunately the households were put into lifethreatening position. Hooghly district of the state is specially known as an economically developed district. By adopting the modern technology it's witness the blooms growth of agriculture and industry as well. About 70 percent households derive their living with engaging agriculture sector and therefore the district holds remarkable position in agriculture. In Hooghly district the growing industries also generated large number of employment but during the lockdown period all sectors were severely affected, many people losses their existing jobs which have affects the pattern of income, spending and savings of households. The paper aims to catch the pattern of households' income, spending and savings in Hooghly district by comparing the scenario of pre-Covid-19 and during pandemic period.

\section{LITERATURE REVIEWS}

The existing literature has found the economic emergent situation in India caused by nationwide implementation of lockdown, nearly 84 percent of households are seeing fall of income since the start lockdown, as per the recent study by the researcher at the, University of Chicago, University of Pennsylvania and the Mumbai-based Centre for Monitoring the Indian Economy (CMIE) (Marianne et al., 2020). Investigation point out household's income negatively affected, the rate of unemployment crossed 27 percent in early month of May as per the CMIE data. Rural sector's household disproportionately more distressed than those in urban sector in India during the period of lockdowns, incomes have fallen 88 percent of rural households, as compared to 75 percent urban household. The study highlighted the pandemic impact on livelihood losses in India and found significant variations of unemployment rate rise across different regions by the nationwide lockdown and the main reason behind this is huge reverse migration. Investigation reported that the states along higher migration and urbanisation rate, large extent of dependency on casual wage employment and other than agricultural employment found adverse impact on people livelihood (Mitra, 2020). Shegunshi \& Hiremath, (2020) discussed the scenario of employment and household income condition in the pre and postlockdown periods, broadly the expecting consequences on the Indian economy mainly informal sector including the poor and the marginalised. The investigation found overall unemployment rate has increased from 8.4 percent to 23.8 percent by the March week ending of 2020 and the proportion of households "falls of income reported" has also increased during lockdown period. Srivastava \& Sivaramane, (2020) examines the consumption pattern of Indian households and found that the consumption pattern has shifted from non-essential to most essential commodities of Indian households during the lockdown period. Singh, (2020) investigate the plight of migrant labourers and COVID19 impact in India's rural economy. The study found nearly 400 million workers of informal economy of India at the risk of falling into poverty during the pandemic period. The study says that the excess pressure will create by the reverse migration on agriculture sector and rural economy and as a result people to fall into abject poverty. Morgan \& Long, (2021) analysed impact of covid-19 on job holding households of eight ADB developing countries like Cambodia, the Lao People's Democratic Republic, Indonesia, Malaysia, Myanmar, the Philippines, Thailand, and Viet Nam. The study found that different households from all considering nations, having at least one person who lost their job or had reduced their actual working time and facing financial difficulties. Baker et al. (2020) using transaction-level household data find that households sharply increased their spending during the initial period in specific sectors such as retail and food spending. These increases, however, were followed by a decrease in overall spending. Lahiri \& Sinha, (2021) determined the socio-economic impact of the COVID-19 pandemic, mainly on changes in consumption as well as occupational patterns of individuals. The analysis found the impact on livelihood of people and mostly whose earnings operation depends on daily running and it had been negatively affected every respondent organization's business by the pandemic. Jana et al. (2021) analyzed the covid-19 effects on rural households in South 24 Pgs. In West Bengal, mainly the households who were engaged as migrant workers and how disrupted they livelihood during nationwide lockdown. The researchers focussed on loss of income, food insecurity/shortage, loss of households' assets, impact on consumption, affects on education and health etc. Janssens et al. (2021) highlighted the in rural Kenya how the lower income group households affected due to covid-19, the study considers the how the households' income reduced after the starts pandemic but households food expenditure was remain same, the study suggests income has decreased nearly one-third after the starting the pandemic.

\section{OBJECTIVES}

The major objectives of the study are

1. To analyze the impact of COVID-19 pandemic on job, income and savings of the household. 
Tanima Choudhuryet al., Sch J Arts HumanitSocSci, Jan, 2022; 10(1): 24-31

2. To comparing different aspects of consumptions and income between pre-COVID-19 and during COVID-19 situation

\section{SCOPE \& DATA}

Hooghly is one of the districts located in West Bengal, India. This is one of most economically blooming districts in the West Bengal. The people are mainly engaged with agriculture but there also have some number of industrial complexes and many people engaged with them, large numbers of people also migrated to other states for earning. This study conducted Primary Survey in a small village name "Beloon" located in this district. A major percentage of people of the district live in rural area and the village also choose from backward with agriculturally dominated area where maximum are engaged with agriculture. Below box present occupation wise number of surveyed households.

\begin{tabular}{|l|c|}
\hline Households occupation & $\begin{array}{c}\text { Number of } \\
\text { household } \\
\text { surveyed }\end{array}$ \\
\hline Casual labour in agriculture & 39 \\
\hline Casual labour in non-agriculture & 16 \\
\hline Regular wage/salary earning & 7 \\
\hline Self-employed in agriculture & 30 \\
\hline Self-employed in non-agriculture & 8 \\
\hline Grand Total & $\mathbf{1 0 0}$ \\
\hline
\end{tabular}

The unemployment rate in India was recorded at nearly 8 percent in pre-covid period; the rate has start increasing due to pandemic. The unemployment data has collect form the CMIE (Centre for Monitoring Indian Economy).

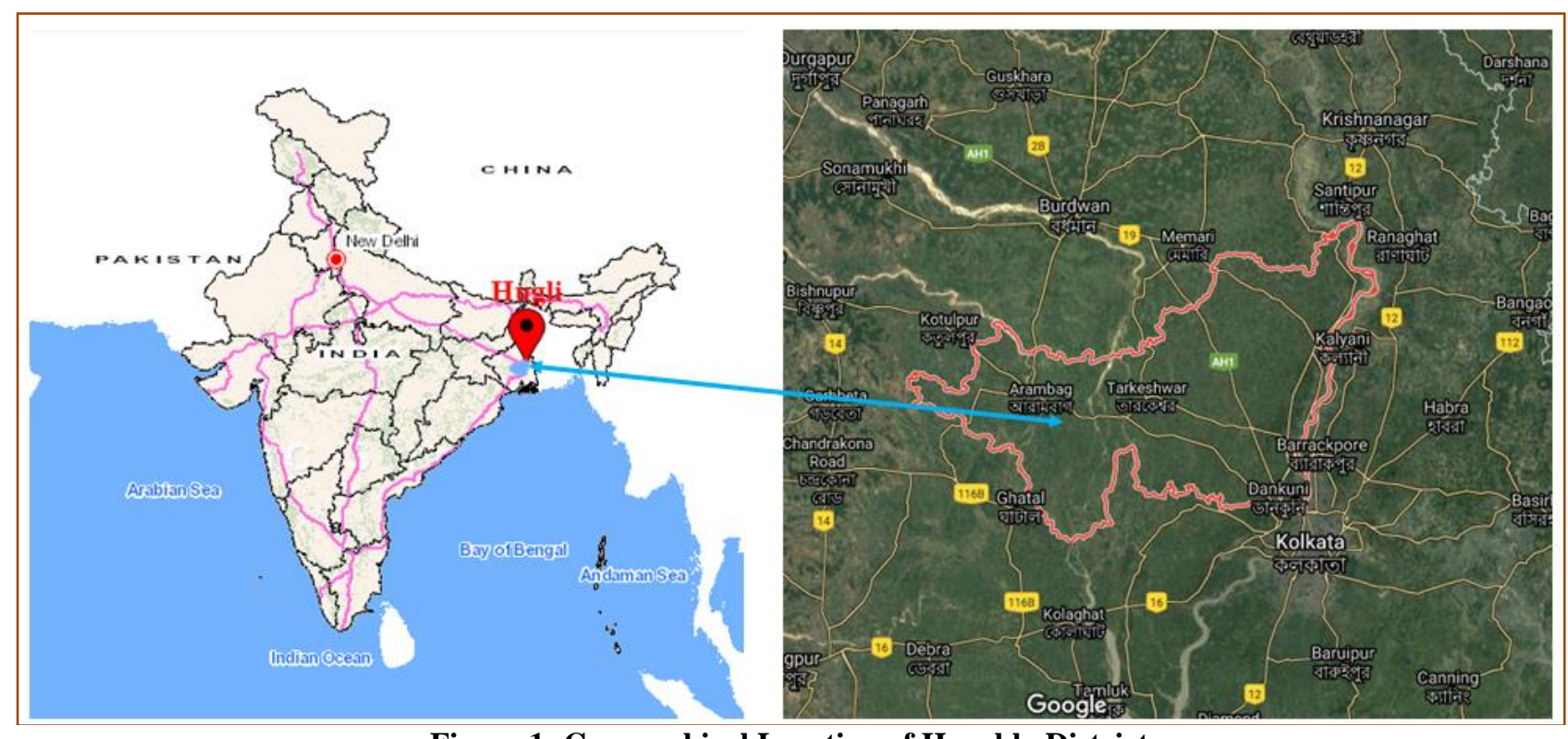

Figure 1: Geographical Location of Hooghly District

Source: Google Map

\section{METHODOLOGY}

For the analysis the method has been employed like Descriptive statistics, Graphical, Presentation, Percentage analysis etc. and comparing pre-Covid and during Covid situation the study has employed Analysis of Variance (ANOVA). ANOVA is one of the techniques for comparing variability of the mean among different groups.

The $\mathrm{F}$ statistic used for testing the hypothesis $\mathrm{H}_{0}: \mu_{1}=$ $\mu_{2}=\ldots . .=\mu_{\mathrm{k}}$ is

$$
F=\frac{\text { Variation among the sample means }}{\text { Variation within the samples }}
$$

The test of significance based on $t$ distribution is an adequate procedure only for testing the significance of the difference between two sample mean.

\section{RESULT \& DISCUSSION}

Firstly, investigation highlights the unemployment scenario in India and West Bengal during the nationwide lockdown period for Covid-19 pandemic. Secondly, the study has focused the impacts of covid-19 pandemic on the households' income, consumption expenditure and savings.

\section{Unemployment situation in West Bengal and India}

In January 2021, India saw an unemployment rate of over six percent. This was a significant improvement from the previous month. A damaging impact on an economy as large as India's caused due a total lockdown was imminent. Unemployment went up 
to nearly 24 percent in April 2020. In January 2021, West Bengal saw an unemployment rate 5.2 percent. This was also a significant improvement from the previous quarter. Rural India faced relatively lower unemployment rate compare to urban India. This was possibly a result of a decrease in demand as well as the disruption of workforce faced by companies. Table 1 presents monthly unemployment rate for India and West Bengal during Covid-19 period based on CMIE data.
Figure 2 illustrates that though the rate of unemployment was higher in India as well as West Bengal before start the covid-19 outbreak but after started pandemic the unemployment rate suddenly hike in the months March to June of 2020 and then its start declining.

Table 1: Unemployment Rate (Monthly Time Series \%)

\begin{tabular}{|c|c|c|c|c|}
\hline \multirow[t]{3}{*}{ Month } & \multicolumn{4}{|c|}{ Unemployment Rate (\%) } \\
\hline & \multirow[t]{2}{*}{ West Bengal } & \multicolumn{3}{|c|}{ India } \\
\hline & & Total & Urban & Rural \\
\hline Aug-2019 & 6.1 & 8.2 & - & - \\
\hline Sep-2019 & 6.4 & 7.1 & - & - \\
\hline Oct-2019 & 7.1 & 8.1 & - & - \\
\hline Nov-2019 & 6.1 & 7.2 & - & - \\
\hline Dec-2019 & 6.2 & 7.6 & - & - \\
\hline Jan-2020 & 6.9 & 7.2 & - & - \\
\hline Feb-2020 & 4.9 & 7.8 & - & - \\
\hline Mar-2020 & 6.9 & 8.8 & - & - \\
\hline Apr-2020 & 17.4 & 23.5 & 24.95 & 22.89 \\
\hline May-2020 & 17.4 & 21.7 & 23.14 & 21.11 \\
\hline Jun-2020 & 7.3 & 10.2 & 11.68 & 9.49 \\
\hline Jul-2020 & 6.8 & 7.4 & 9.37 & 6.51 \\
\hline Aug-2020 & 14.9 & 8.3 & 9.83 & 7.65 \\
\hline Sep-2020 & 9.3 & 6.7 & 8.45 & 5.88 \\
\hline Oct-2020 & 10.2 & 7 & 7.18 & 6.95 \\
\hline Nov-2020 & 11.2 & 6.5 & 7.07 & 6.24 \\
\hline Dec-2020 & 6 & 9.1 & 8.84 & 9.15 \\
\hline Jan-2021 & 5.2 & 6.5 & 8.08 & 5.83 \\
\hline Feb-2021 & 6.2 & 6.9 & 6.99 & 6.86 \\
\hline Mar-2021 & 7.5 & 6.5 & 7.24 & 6.19 \\
\hline
\end{tabular}

Source: CMIE (Centre for Monitoring Indian Economy)

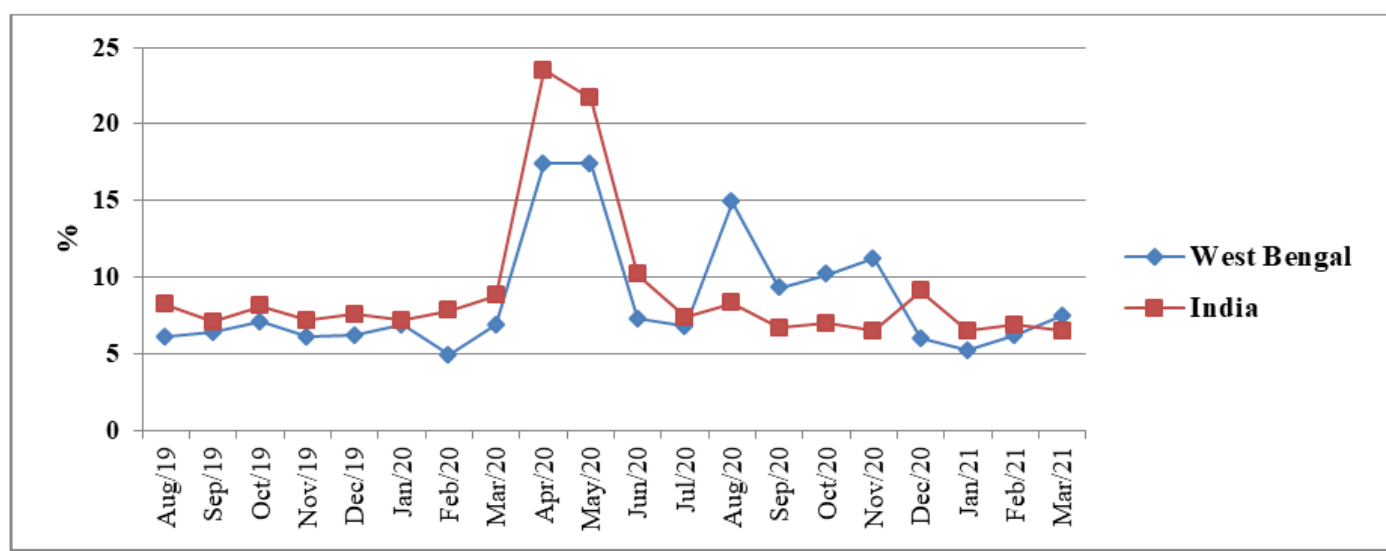

Figure 2: Impact on Unemployment Rate due to the COVID 19 lockdown (Monthly Time Series, \%) Source: CMIE

The primary survey data reveals 42 percent people's losses their jobs during Covid-19 lockdown. Most of the causal labour and self employed persons engaged in non-agriculture sector losses their jobs due to this lockdown. Regular wage/salary earner less affected by this lockdown. Table 2 presents occupation wise percentage of households' losses their jobs during Covid-19 situation. 
Tanima Choudhuryet al., Sch J Arts HumanitSocSci, Jan, 2022; 10(1): 24-31

Table 2: Occupation wise percentage of people (Household Head) losses their jobs during Covid-19 lockdown

\begin{tabular}{|c|c|c|c|c|}
\hline \multirow{2}{*}{$\begin{array}{l}\text { Occupational Distribution according } \\
\text { to NSSO }\end{array}$} & \multicolumn{2}{|c|}{ Job Loss } & \multirow{2}{*}{$\begin{array}{c}\text { Grand } \\
\text { Total }\end{array}$} & \multirow{2}{*}{$\begin{array}{c}\text { \% of households' losses } \\
\text { their jobs }\end{array}$} \\
\hline & No & Yes & & \\
\hline Casual labour in agriculture & 22 & 17 & 39 & 43.6 \\
\hline Casual labour in non-agriculture & 6 & 10 & 16 & 62.5 \\
\hline Regular wage/salary earning & 6 & 1 & 7 & 14.3 \\
\hline Self-employed in agriculture & 20 & 10 & 30 & 33.3 \\
\hline Self-employed in non-agriculture & 4 & 4 & 8 & 50 \\
\hline Grand Total & 58 & 42 & 100 & 42 \\
\hline
\end{tabular}

Source: author's calculation (Primary Survey)

Comparing pre-COVID and during COVID situation of household Income, Expenditure and Savings

The people of surveyed village are mainly engaged with casual works, some of the households' have regular wage/salary earner. But due to sudden shock most the earning members' losses their jobs, consequently sudden fall in income level the affect found in consumption expenditure and savings of the households.

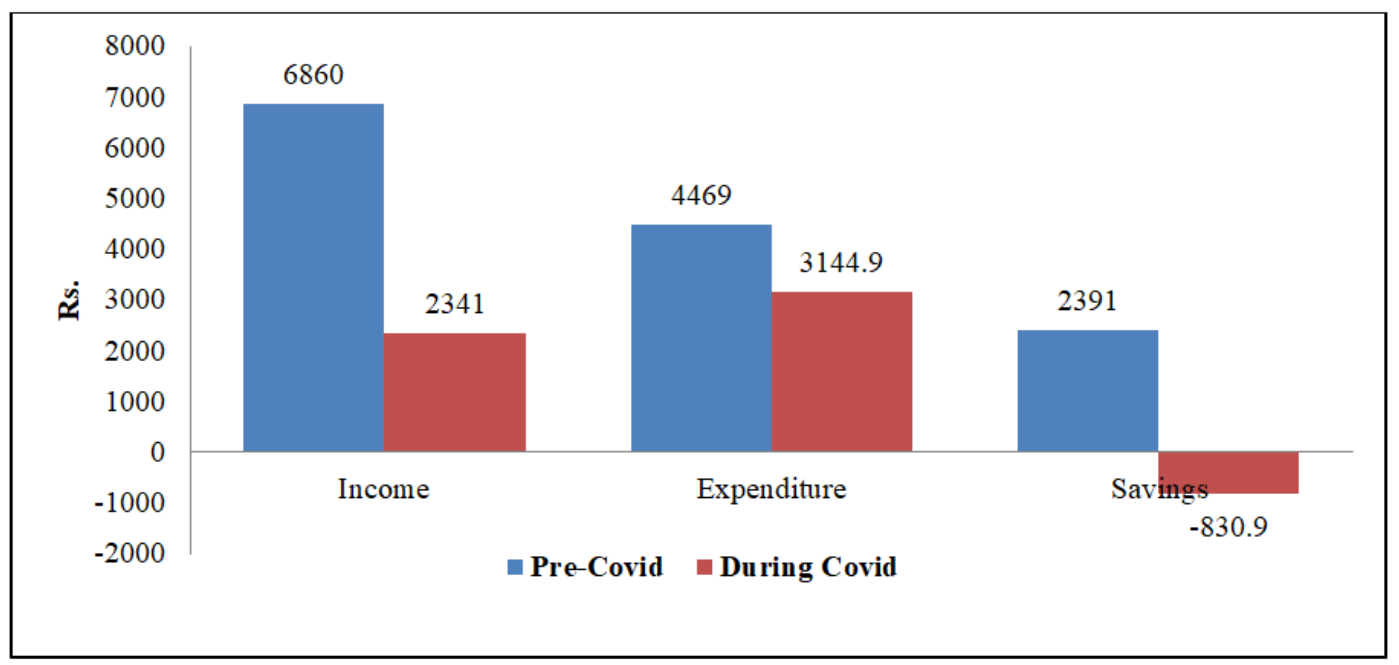

Figure 3: Covid-19 lockdown Impact on Income, Expenditure and Savings (per household). Source: Primary Survey

Table 3: Income Expenditure Situation of Households in Pre-Covid and During Covid

\begin{tabular}{|c|c|c|c|c|c|c|c|c|}
\hline & & Mean & Median & Mode & SD & Minimum & Maximum & Range \\
\hline \multirow{2}{*}{$\begin{array}{l}\text { Household Income } \\
\text { (INR) }\end{array}$} & Pre-Covid & 6860.0 & 6000 & 6000 & 3632.12 & 1000 & 22000 & 21000 \\
\hline & During Covid & 2314.0 & 2000 & 0 & 2976.58 & 0 & 22000 & 22000 \\
\hline \multirow{2}{*}{$\begin{array}{l}\text { Household Consumption } \\
\text { Expenditure (INR) }\end{array}$} & Pre-Covid & 4469.0 & 4000 & 3000 & 2284.75 & 700 & 15000 & 14300 \\
\hline & During Covid & 3144.9 & 2545 & 1500 & 1861.88 & 500 & 9000 & 8500 \\
\hline \multirow{2}{*}{$\begin{array}{l}\text { Number of Earning } \\
\text { Members/household }\end{array}$} & Pre-Covid & 1.3 & 1 & 1 & 0.53 & 1 & 3 & 2 \\
\hline & During Covid & 0.9 & 1 & 1 & 0.62 & 0 & 3 & 3 \\
\hline \multirow{2}{*}{$\begin{array}{l}\text { Electricity Consumption } \\
\text { (in INR) }\end{array}$} & Pre-Covid & 283.7 & 233 & 300 & 261.67 & 0 & 1500 & 1500 \\
\hline & During Covid & 259.7 & 202.5 & 250 & 240.85 & 0 & 1500 & 1500 \\
\hline \multirow{2}{*}{$\begin{array}{l}\text { Vegetable Consumption } \\
\text { (in INR) }\end{array}$} & Pre-Covid & 39.5 & 30 & 30 & 32.31 & 10 & 150 & 140 \\
\hline & During Covid & 56.8 & 50 & 50 & 37.44 & 0 & 200 & 200 \\
\hline \multirow[t]{2}{*}{ Rice Cost (Per Kg) } & Pre-Covid & 26.7 & 26 & 25 & 2.55 & 20 & 35 & 15 \\
\hline & During Covid & 30.6 & 30 & 30 & 2.75 & 26 & 39 & 13 \\
\hline \multirow[t]{2}{*}{ Pulses Cost (per Kg) } & Pre-Covid & 94.5 & 95 & 95 & 4.32 & 80 & 100 & 20 \\
\hline & During Covid & 123.8 & 120 & 120 & 9.67 & 100 & 150 & 50 \\
\hline \multirow[t]{2}{*}{ Chicken Cost (per Kg) } & Pre-Covid & 95.9 & 95 & 100 & 6.82 & 80 & 130 & 50 \\
\hline & During Covid & 145.3 & 150 & 150 & 14.39 & 100 & 160 & 60 \\
\hline \multirow[t]{2}{*}{ Fish Cost (Per Kg) } & Pre-Covid & 105.4 & 100 & 100 & 20.35 & 80 & 200 & 120 \\
\hline & During Covid & 157.6 & 150 & 150 & 30.48 & 110 & 250 & 140 \\
\hline \multirow[t]{2}{*}{ Egg (1 piece) } & Pre-Covid & 5.1 & 5 & 5 & 0.44 & 4 & 8 & 4 \\
\hline & During Covid & 6.8 & 6.25 & 6 & 0.96 & 6 & 10 & 4 \\
\hline
\end{tabular}

Source: Primary Survey 
Tanima Choudhuryet al., Sch J Arts HumanitSocSci, Jan, 2022; 10(1): 24-31

Figure 3 presents average household expenditure, Income and savings for pre Covid-19 and during Covid-19 period. Income, expenditure and savings significantly decrease during Covid-19 situation. It is clearly shows that before the pandemic average household monthly income was INR 6860/- but after the start of covid-19 outbreak the income of the sample households falls to INR 2341/-. Before pandemic household monthly expenditure was 4469/but during the covid-19 period it is falls to INR 3144.9/per month. The figure also shows that during the pandemic period savings found negative, as the households fulfil the income and expenditure gap from their previous savings or taking loan. During covid-19 period overall consumption expenditure decreased but food expenditure increased (see table 3 ).

The table 3 explores the scenario of households' income, consumption expenditure details in both the pre-covid and during covid period. It is observed that households have direct affect on income and consumption expenditure, both has decreased but income decreased more than the consumption expenditure. Though the households' earnings members lost their jobs but people were unable to reduce their necessary consumptions, the people only could stop spending on the luxuries during the pandemic period. Even it has been seen that the spending on some specific items increased during the pandemic period. The expenses on electricity and food (like, Vegetable, rice, pulses, chicken, fishes, egg etc.) have increased in this period.
ANOVA Analysis for comparing household Income, Expenditure and Savings between two groups

To decode the scenario of covid-19 impact, the surveyed households categorized into two groups as given below-

Group-1: No earning member of the household loss his/her job due to covid-19 lockdown situation;

Group-2: At least one earning member of the household loss his/her job due to covid-19 lockdown situation

For comparing two groups we formulate the following null hypothesis-

1A) $\mathrm{H}_{0}=$ There is no significant difference in the household income between two above mentioned groups during pre-Covid.

1B) $\mathrm{H}_{0}=$ There is no significant difference in the household income between two above mentioned groups during Covid.

2A) $\mathrm{H}_{0}=$ There is no significant difference in the household expenditure between two above mentioned groups during pre-Covid.

2B) $\mathrm{H}_{0}=$ There is no significant difference in the household expenditure between two above mentioned groups during Covid.

3A) $\mathrm{H}_{0}=$ There is no significant difference in the household savings between two above mentioned groups during pre-Covid.

3B) $\mathrm{H}_{0}=$ There is no significant difference in the household Savings between two above mentioned groups during Covid.

ANOVA analysis has been made based on above mentioned hypothesis and the results presented in table $4 \mathrm{~A}$ and $4 \mathrm{~B}$.

Table 4A: Descriptive Statistics (by Two Groups)

\begin{tabular}{|c|c|c|c|c|c|c|c|}
\hline & & Category & $\mathbf{N}$ & Mean & Std. Deviation & Minimum & Maximum \\
\hline \multirow{3}{*}{$1 \mathrm{~A}$} & \multirow{3}{*}{ Household Income (Pre Covid) } & Group-1 & 58 & 6939.7 & 3483.1 & 2000 & 22000 \\
\hline & & Group-2 & 42 & 6750.0 & 3868.7 & 1000 & 18000 \\
\hline & & Total & 100 & 6860.0 & 3632.1 & 1000 & 22000 \\
\hline \multirow{3}{*}{ 1B } & \multirow{3}{*}{ Household Income (During Covid) } & Group-1 & 58 & 2989.7 & 3157.3 & 100 & 22000 \\
\hline & & Group-2 & 42 & 1381.0 & 2449.0 & 0 & 12000 \\
\hline & & Total & 100 & 2314.0 & 2976.6 & 0 & 22000 \\
\hline \multirow{3}{*}{$2 \mathrm{~A}$} & \multirow{3}{*}{ Household Expenditure (Pre Covid) } & Group-1 & 58 & 4653.4 & 2093.4 & 1500 & 12000 \\
\hline & & Group-2 & 42 & 4214.3 & 2529.4 & 700 & 15000 \\
\hline & & Total & 100 & 4469.0 & 2284.8 & 700 & 15000 \\
\hline \multirow{3}{*}{$2 \mathrm{~B}$} & \multirow{3}{*}{ Household Expenditure (During Covid) } & Group-1 & 58 & 3320.7 & 1784.1 & 500 & 7000 \\
\hline & & Group-2 & 42 & 2902.1 & 1959.9 & 500 & 9000 \\
\hline & & Total & 100 & 3144.9 & 1861.9 & 500 & 9000 \\
\hline \multirow{3}{*}{$3 \mathrm{~A}$} & \multirow{3}{*}{ Household Savings (Pre Covid) } & Group-1 & 58 & 2286.2 & 2911.1 & 0 & 20000 \\
\hline & & Group-2 & 42 & 2535.7 & 2625.5 & -3000 & 11500 \\
\hline & & Total & 100 & 2391.0 & 2783.8 & -3000 & 20000 \\
\hline \multirow{3}{*}{$3 \mathrm{~B}$} & \multirow{3}{*}{ Household Savings (During Covid) } & Group-1 & 58 & -331.0 & 3330.2 & -4200 & 20000 \\
\hline & & Group-2 & 42 & -1521.2 & 1722.5 & -4000 & 6000 \\
\hline & & Total & 100 & -830.9 & 2821.8 & -4200 & 20000 \\
\hline
\end{tabular}

Source: Author's Estimation, Primary survey 
Tanima Choudhuryet al., Sch J Arts HumanitSocSci, Jan, 2022; 10(1): 24-31

Table 4B: ANOVA Result

\begin{tabular}{|c|c|c|c|c|c|c|c|}
\hline & & & Sum of Squares & df & Mean Square & $\mathbf{F}$ & Sig. \\
\hline \multirow{3}{*}{$1 \mathrm{~A}$} & \multirow{3}{*}{ Household Income (Pre Covid) } & Between Groups & 876206.9 & 1 & 876206.9 & \multirow{3}{*}{0.066} & \multirow{3}{*}{0.798} \\
\hline & & Within Groups & $1.31 \mathrm{E}+09$ & 98 & $1.33 \mathrm{E}+07$ & & \\
\hline & & Total & $1.31 \mathrm{E}+09$ & 99 & & & \\
\hline \multirow{3}{*}{ 1B } & \multirow{3}{*}{ Household Income (During Covid) } & Between Groups & $6.30 \mathrm{E}+07$ & 1 & $6.30 \mathrm{E}+07$ & \multirow{3}{*}{7.589} & \multirow{3}{*}{0.007} \\
\hline & & Within Groups & $8.14 \mathrm{E}+08$ & 98 & 8307128.1 & & \\
\hline & & Total & $8.77 \mathrm{E}+08$ & 99 & & & \\
\hline \multirow{3}{*}{$2 \mathrm{~A}$} & \multirow{3}{*}{ Household Expenditure (Pre Covid) } & Between Groups & 4698161 & 1 & 4698161.1 & \multirow{3}{*}{0.899} & \multirow{3}{*}{0.345} \\
\hline & & Within Groups & $5.12 \mathrm{E}+08$ & 98 & 5225415.7 & & \\
\hline & & Total & $5.17 \mathrm{E}+08$ & 99 & & & \\
\hline \multirow{3}{*}{$2 \mathrm{~B}$} & \multirow{3}{*}{ Household Expenditure (During Covid) } & Between Groups & 4267419 & 1 & 4267419.4 & \multirow{3}{*}{1.234} & \multirow{3}{*}{0.269} \\
\hline & & Within Groups & $3.39 \mathrm{E}+08$ & 98 & 3458429.4 & & \\
\hline & & Total & $3.43 \mathrm{E}+08$ & 99 & & & \\
\hline \multirow{3}{*}{$3 \mathrm{~A}$} & \multirow{3}{*}{ Household Savings (Pre Covid) } & Between Groups & 1516506 & 1 & 1516505.9 & \multirow{3}{*}{0.194} & \multirow{3}{*}{0.66} \\
\hline & & Within Groups & $7.66 \mathrm{E}+08$ & 98 & 7813065.2 & & \\
\hline & & Total & $7.67 \mathrm{E}+08$ & 99 & & & \\
\hline \multirow{3}{*}{$3 \mathrm{~B}$} & \multirow{3}{*}{ Household Savings (During Covid) } & Between Groups & $3.45 \mathrm{E}+07$ & 1 & $3.45 \mathrm{E}+07$ & \multirow{3}{*}{4.486} & \multirow{3}{*}{0.037} \\
\hline & & Within Groups & $7.54 \mathrm{E}+08$ & 98 & 7691718.1 & & \\
\hline & & Total & $7.88 \mathrm{E}+08$ & 99 & & & \\
\hline
\end{tabular}

Source: Author's Estimation, Primary survey

\section{RESULT}

1A) There is no significant difference in the household income between two above mentioned groups during pre-Covid, as p-value of the F-statistic is 0.798. Thus, we fall to reject the null hypothesis, that's why we accept null hypothesis.

1B) There is significant difference in the household income between two above mentioned groups during Covid at $1 \%$ level of significance as p-value of the output is .007, thus the null hypothesis is rejected.

2A) There is no significant difference in the household expenditure between two above mentioned groups during pre-Covid, as p-value of the F-statistic is 0.345 . Thus, we fall to reject the null hypothesis, that's why we accept null hypothesis.

2B) There is no significant difference in the household expenditure between two above mentioned groups during Covid, as p-value of the F-statistic is 0.269. Thus, we fall to reject the null hypothesis, that's why we accept null hypothesis.

3A) There is no significant difference in the household savings between two above mentioned groups during pre-Covid, as p-value of the F-statistic is 0.66. Thus, we fall to reject the null hypothesis, that's why we accept the null hypothesis.

3B) There is significant difference in the household savings between two above mentioned groups during Covid at $5 \%$ level of significance as p-value of the output is .037 , thus the null hypothesis is rejected.

\section{CONCLUSION}

The COVID-19 pandemic has caused one of the greatest shocks all over the India after declared the nationwide lockdown; most of the economic activities have stopped. Many people losses their jobs especially those were engaged in informal sectors which directly affects the households' income, consumption, and savings. The purchasing behaviour of household has changed during this situation. Currently, India has facing a negative GDP growth rate. Unemployment went up to nearly 24 percent and 18 percent in India and West Bengal respectively in April 2020. Both income and consumption has decreased but income decreased more than the consumption expenditure. The study also found that overall consumption expenditure decreased but food expenditure increased, that's why people have broken their savings for maintaining food expenditure during this situation.

\section{REFERENCES}

- Anand, G., \& Kumar, H. (2016). Indian vendors see empty stores and blame a rupee ban. The New York

Times. https://www.nytimes.com/2016/11/24/world/asia/ india-currency-narendra-modi.html.

- Lahiri, S., \& Sinha, M. (2021). A study of the socio-economic implications of the COVID-19 pandemic. Australasian Accounting, Business and Finance Journal, 15(1 Special Issue), 51-69. https://doi.org/10.14453/aabfj.v15i1.5

- Marianne, B., K., K., \& H., S. (2020). How the COVID-19 Lockdown Is Affecting India's Households. Article: Knowledge @WHARTON, 17.https://knowledge.wharton.upenn.edu/article/covi d-19-lockdown-affecting-indias-households/

- Mishra, K., \& Rampal, J. (2020). The COVID-19 pandemic and food insecurity: A viewpoint on India. World Development, 135, 105068. https://doi.org/10.1016/j.worlddev.2020.105068

- Mitra, A. (2020). COVID-19 Pandemic and Livelihood Loss: Variations in Unemployment Outcomes and Lessons for Future. IEG Working Paper, Sr. No 405.

- Morgan, P. J., \& Long, T. Q. (2021). Impacts of COVID-19 on Households in ASEAN Countries and Their Implications for Human Capital 
Tanima Choudhuryet al., Sch J Arts HumanitSocSci, Jan, 2022; 10(1): 24-31

Development (Issue 1226). https://www.adb.org/publications/impacts-covid19-households-asean-countries

- Shegunshi, M. P., \& Hiremath, G. N. (2020). Covid-19 Impact on Indian Labour Class. IX(Vi), 6324-6330.

- Singh, B. P. (2020). Munich Personal RePEc Archive Impact of COVID-19 on Rural Economy in India. Munich Personal RePEc Archive (MPRA), Paper No(100530).

- Srivastava, S. K., \& Sivaramane, N. (2020). Income-induced effects of COVID-19 on the food consumption pattern of Indian households. Agricultural Economics Research Review, 33(Conference Number), 15-24. https://doi.org/10.5958/0974-0279.2020.00014.2

- $\quad$ Baker, S. R., Farrokhnia, R. A., Meyer, S., Pagel, M., \& Yannelis, C. (2020). How Does Household
Spending Respond to an Epidemic? Consumption During the 2020 COVID-19 Pandemic (Working Paper No. 26949; Working Paper Series). National Bureau of Economic Research. https://doi.org/10.3386/w26949

- Jana, S. K., Naru, S., \& Paul, P. K. (2022). COVID-19 and the Livelihoods of the Migrant Workers: A Study in Rural West Bengal, India. In Economic Impact and Recovery Following a Global Health Crisis (pp. 172-189). IGI Global.

- Janssens, W., Pradhan, M., de Groot, R., Sidze, E., Donfouet, H. P. P., \& Abajobir, A. (2021). The short-term economic effects of COVID-19 on lowincome households in rural Kenya: An analysis using weekly financial household data. World Development, $138, \quad 105280$. https://doi.org/10.1016/j.worlddev.2020.105280 